\title{
Toxicological Effects of Dietary Biogenic Amines
}

*Victor Ladero, Marina Calles, María Fernández and Miguel A. Alvarez

Instituto de Productos Lácteos de Asturias (IPLA-CSIC), 33300 Villaviciosa, Asturias, Spain.

Corresponding author: Miguel A. Alvarez.

Instituto de Productos Lácteos de Asturias (CSIC),

Apdo. de Correos 85,

33300 Villaviciosa,

Asturias, Spain.

Tel: +34985892131.

Fax: +34985892233.

E-mail:maag@ipla.csic.es 


\begin{abstract}
Biogenic amines (BAs) are defined as low molecular weight organic bases with biological activity. They are formed and degraded as part of the normal metabolism of microorganisms, plants and animals, in which they have important physiological functions. In humans, BAs are involved in brain activity, the regulation of body temperature and stomach $\mathrm{pH}$, gastric acid secretion, the immune response, and cell growth and differentiation etc. However, the consumption of foods with high concentrations of BAs can induce adverse reactions such as nausea, headaches, rashes and changes in blood pressure. The accumulation of BAs in the food matrix is mainly due to the presence of bacteria able to decarboxylate certain amino acids. The most common and powerful BAs found in food are histamine, tyramine and putrescine. Their contents vary, sometimes reaching over $2 \mathrm{~g}$ per $\mathrm{kg}$. Histamine is the only BA for which maximum levels in food have been set, although general interest exists in reducing the presence of all BAs in all food products. This review discusses the toxic effects of BAs when ingested with food.
\end{abstract}

Key words: biogenic amines, food products, physiology, toxicology, microbiology, regulation. 


\section{Introduction}

Biogenic amines (BAs) are low molecular weight organic bases with an aliphatic (putrescine, cadaverine, spermine, spermidine) aromatic (tyramine, phenylethylamine) or heterocyclic (histamine, tryptamine) structure. All are invested with biological activity. They are formed and degraded as part of the normal metabolism of animals, plants and microorganisms. Their accumulation in food products is largely due to the presence of microorganisms with decarboxylase activity; the removal of the alpha carboxyl group from an amino acid produces its corresponding BA.

In general, the name of a BA is assigned depending on the name of the amino acid giving rise to it; thus, histamine is the BA formed from histidine, tyramine is that formed from tyramine, tryptamine is that formed from tryptophan, and phenylethylamine that formed from phenylalanine. However, cadaverine is synthesized from lysine, and putrescine is formed by the decarboxylation of ornithine or the decarboxylation of arginine and the subsequent deamination of the product.

BAs play important roles in human brain activity, the regulation of body temperature and stomach $\mathrm{pH}$, gastric acid secretion, the immune response, and cell growth and differentiation etc. However, an excessive oral intake of BAs can induce adverse reactions such as nausea, headaches, rashes and change in blood pressure. This is especially true in sensitive individuals and in those in whom BA detoxification is impaired.

In this review, the physiological functions of BAs are examined, as are their toxicological effects following the ingestion of foods containing high concentrations. The microorganisms responsible for their synthesis are also discussed, the recommendable limits of BAs in foodstuffs considered, and the possibilities of detecting BA-producing bacteria examined. 
Table 1. Physiological and toxicological effects of biogenic amines.

\begin{tabular}{|c|c|c|}
\hline$\overline{\mathrm{BA}}$ & Physiological Effects & Toxicological effects \\
\hline Histamine & $\begin{array}{l}\text { Neurotransmitter, local hormone, } \\
\text { gastric acid secretion, cell growth } \\
\text { and differentiation, regulation of } \\
\text { circadian rhythm, body } \\
\text { temperature, food intake, learning } \\
\text { and memory, immune response, } \\
\text { allergic reactions }\end{array}$ & $\begin{array}{l}\text { headaches, sweating, burning nasal } \\
\text { secretion, facial flushing, bright red } \\
\text { rashes, dizziness, itching rashes, } \\
\text { oedema (eyelids), urticaria, } \\
\text { difficulty in swallowing, diarrhoea, } \\
\text { respiratory distress, bronchospasm, } \\
\text { increased cardiac output, } \\
\text { tachycardia, extrasystoles, blood } \\
\text { pressure disorders }\end{array}$ \\
\hline Tyramine & $\begin{array}{l}\text { Neurotransmitter, } \\
\text { peripheral vasoconstriction, } \\
\text { increase cardiac output, increase } \\
\text { respiration, elevate blood glucose, } \\
\text { release of norepinephrine }\end{array}$ & $\begin{array}{l}\text { headaches, migraine, neurological } \\
\text { disorders, nausea, vomiting, } \\
\text { respiratory disorders, hypertension. }\end{array}$ \\
\hline Putrescine & $\begin{array}{l}\text { regulation of gene expression } \\
\text { maturation of intestine, cell } \\
\text { growth and differentiation }\end{array}$ & $\begin{array}{l}\text { increased cardiac } \\
\text { tachycardia, } \\
\text { carcinogenic effects }\end{array}$ \\
\hline
\end{tabular}

\section{Physiological role of amines}

BAs play a number of crucial roles in the physiology and development of eukaryotic cells $[1,2]$ their physiological role is summarized in table 1 . The most active BAs are histamine and tyramine. Polyamines such as putrescine, spermine and spermidine also play essential roles in cell growth and differentiation via the regulation of gene expression and the modulation of signal transduction pathways.

Histamine is present in many living tissues as a normal constituent of the body and has multiple effects in different mammalian and invertebrate organs [3, 4]. In humans, it is found in different concentrations in the brain, lung, stomach, small and large intestine, uterus and the ureters. It is produced and stored predominantly in mast cells, circulating basophiles and neurons. Histamine modulates a variety of functions by interacting with specific receptors on target cells, namely $\mathrm{H} 1, \mathrm{H} 2$ and $\mathrm{H} 3$, receptors of the G-protein- 
coupled receptor family. $\mathrm{H} 1$ receptors are found in the brain where they are involved in the control of the circadian rhythm, attention and cognition, and in peripheral tissues where they mediate vascular and bronchial muscle responses to histamine in allergic processes [5]. $\mathrm{H} 2$ receptors, although widely distributed in body tissues, seem to have a central role only in the regulation of acid secretion. They respond to the presence of histamine, provoking gastric acid secretion and the contraction of intestinal smooth muscle [6]. H3 receptors, originally described as presynaptic autoreceptors on brain histaminergic neurons that controlled histamine synthesis and release, were subsequently recharacterised as heteroreceptors on non-histaminergic neurons in the central and peripheral nervous systems. They have also been found on paracrine and immune cells and in smooth muscle [7,8] where they have been associated with immediate and allergic hypersensitivity. When histamine binds with these receptors they effect the contraction of smooth muscle cells, the dilation of blood vessels and, therefore, an efflux of blood serum into the surrounding tissues (including the mucous membranes), initiating the inflammatory process $[3,6]$.

Tyramine and $\beta$-phenylethylamine are included in the group of trace amines, a family of endogenous compounds with strong structural similarities to classical monoamine neurotransmitters, although the endogenous levels of these compounds are at least two orders of magnitude below that of these neurotransmitters. The effects of these low physiological concentrations have been difficult to demonstrate, but it has been suggested that they serve to maintain the neuronal activity of monoamine neurotransmitters within defined physiological limits [9]. Interest in their functionality has increased in recent decades following the discovery of a new family of G-protein coupled receptors (GPCR), some of which are specifically activated by trace amines [9]. This specificity has led to the proposal of a new nomenclature for these receptors, that of trace amine-associated receptors (TAARs) [10]. Some of these receptors are located in blood vessels, which might explain the effect of tyramine on blood pressure [11]. Tyramine can be converted into octopamine when taken up in sympathetic nerve terminals, where it displaces norepinephrine (NE) from storage vesicles. A portion of this NE diffuses out of the nerve to react with receptors, causing hypertension and other sympathomimetic effects [9]. 
The physiological role of polyamines has been related to their chemical structure. These molecules carry a positive charge on their primary and secondary amino groups at physiological pH. Thus, polyamines may act as ligands at multiple sites on DNA, RNA, proteins, phospholipids and nucleotide triphosphates. The biological functions of polyamines are mainly the regulation of gene expression by altering DNA structure and by modulating signal transduction pathways. The optimal functioning of the cell therefore requires the intracellular polyamine content be strictly controlled at the levels of biosynthesis, catabolism, uptake and efflux [12]. Small amounts of orally administrated polyamines induce cell growth; larger quantities have no effect or may actually inhibit growth [13].

The observation that polyamines play a role in the maturation of the intestine, even when administrated orally [14], indicates that dietary polyamines may be of importance in the normal development of the digestive tract. In humans in particular, these substances could play a role in the prevention of food allergies [15]. 
Table 2. BA content in different food products.

\begin{tabular}{|c|c|c|c|c|c|c|c|}
\hline \multicolumn{8}{|c|}{ BA $\left(\mathrm{mg} \mathrm{l}^{-1}\right.$ o $\left.\mathrm{mg} \mathrm{kg}^{-1}\right)$} \\
\hline Food & Tyramine & Histamine & Putrescine & Cadaverine & $\begin{array}{c}\text { Phenylethyla } \\
\text { mine }\end{array}$ & Spermidine & Reference \\
\hline \multicolumn{8}{|l|}{ Vegetables } \\
\hline Lettuce & 1 & - & 10 & - & 10 & 16 & [16] \\
\hline Spinach & 8 & 2.0 & 8 & - & 1 & 23 & [16] \\
\hline Potato & 7 & - & 10 & - & - & 10 & [16] \\
\hline Zucchini (courgettes) & - & - & 49 & - & 2 & 10 & [16] \\
\hline Onion & 2 & - & 3 & - & 1 & 4 & [16] \\
\hline Tomato concentrate & 10.4 & 4.6 & 25.9 & 5.8 & - & 8.4 & [17] \\
\hline Ketchup & 33.6 & 6.5 & 52.5 & 30.7 & - & 6.1 & [17] \\
\hline Fermented soy & - & 4620 & 12340 & 6340 & - & - & [18] \\
\hline \multicolumn{8}{|l|}{ Fish } \\
\hline Tuna Fillet & $\mathrm{Nd}$ & - & $\mathrm{Nd}$ & $\mathrm{Nd}$ & $\mathrm{Nd}$ & $\mathrm{Nd}$ & [19] \\
\hline Fresh fish & 61.8 & 23.4 & - & - & - & - & [20] \\
\hline Fish for 2 day & 198 & 209 & 834 & 233 & - & 4.7 & [20] \\
\hline Fish sauce & - & 140 & - & - & - & - & [21] \\
\hline Smoked mackerel & - & 17880 & 490 & 2520 & - & - & [18] \\
\hline Tuna (canned) & - & 20000 & 2000 & 4470 & - & - & {$[18]$} \\
\hline \multicolumn{8}{|l|}{ Fermented drinks } \\
\hline Must & 0.0 & 0.0 & 12.33 & 12.9 & 6.44 & - & [22] \\
\hline Wine & 19 & 25 & 55 & 14 & 16.26 & - & [22] \\
\hline Red wine & 18.2 & 19.6 & 99.9 & 1.0 & 1.4 & 2.64 & [23] \\
\hline White wine & 2.3 & 1.1 & 9.7 & 0.6 & 1.7 & 1.5 & [23] \\
\hline Cider & 4.08 & 6.93 & 12.25 & - & - & - & [24] \\
\hline Beer & 3.6 & 3.0 & 7.6 & 1.3 & - & - & [17] \\
\hline Beer & 10.5 & 8.8 & 11.9 & 50.7 & - & - & [17] \\
\hline \multicolumn{8}{|l|}{ Fermented meat } \\
\hline Dry fermented sausages & 273 & 57 & 144 & 81 & - & 18 & [25] \\
\hline $\begin{array}{l}\text { Sorpresa (typical Italian } \\
\text { sausage) }\end{array}$ & 214 & - & 231 & 66 & - & 17 & [25] \\
\hline Dry-cured ham & 104 & 114 & 97 & 64 & - & 16 & [25] \\
\hline Dry cured belly pork & 295 & 114 & 331 & 6 & - & 16 & [25] \\
\hline Fresh meat & 38 & - & - & - & - & 19 & [25] \\
\hline $\begin{array}{l}\text { Chorizo (Spanish ripened } \\
\text { meat sausage) }\end{array}$ & 282.38 & 17.5 & 60.4 & 20.1 & 1.2 & - & [26] \\
\hline $\begin{array}{l}\text { Fuet (Spanish ripened } \\
\text { sausage) }\end{array}$ & 156.9 & 15.2 & 64.7 & 367.2 & 10.1 & 10.3 & [23] \\
\hline $\begin{array}{l}\text { Chopped pork (cooked } \\
\text { meat product) }\end{array}$ & 17.6 & 1.4 & - & - & - & - & [27] \\
\hline & & & & & & & \\
\hline
\end{tabular}




\begin{tabular}{|c|c|c|c|c|c|c|c|}
\hline Dairy products & & & & & & & \\
\hline Milk & & & 0.013 & - & - & 0.086 & {$[28]$} \\
\hline Yoghurt & - & $\leq 1.3$ & - & - & - & - & [29] \\
\hline Feta cheese & 246 & 846 & 193 & 828 & 4.94 & - & {$[30]$} \\
\hline Terrincho cheese & 216.2 & 15.6 & 217.8 & 349.7 & - & - & {$[31]$} \\
\hline Raw goat's milk cheese & 324.6 & 43.06 & 86.4 & 196.4 & 27.3 & - & {$[28]$} \\
\hline $\begin{array}{l}\text { Pasteurised goat's milk } \\
\text { cheese }\end{array}$ & 10.9 & 6.34 & 14.6 & 32.7 & 8.89 & - & {$[28]$} \\
\hline Blue raw milk cheese & 1051 & 1041 & 875.8 & 756.7 & 27.4 & - & {$[32]$} \\
\hline $\begin{array}{l}\text { Blue pasteurised milk } \\
\text { cheese }\end{array}$ & 526.6 & 127 & 237.5 & 89.4 & nd & - & {$[32]$} \\
\hline Unripened raw milk cheese & 233.3 & 110.8 & 38.7 & 96.3 & nd & - & {$[32]$} \\
\hline $\begin{array}{l}\text { Unripened pasteurised milk } \\
\text { cheese }\end{array}$ & 22 & 60.2 & nd & nd & nd & - & [32] \\
\hline Ripened raw milk cheese & 453.7 & 510.2 & 176.3 & 328.4 & 40.7 & - & {$[32]$} \\
\hline $\begin{array}{l}\text { Ripened pasteurised milk } \\
\text { cheese }\end{array}$ & 301 & 65.4 & 175.3 & & & - & [32] \\
\hline
\end{tabular}

\section{Dietary amines}

BAs are present in many different foods and beverages, although their concentrations vary widely between and even within food types. In addition, they may not be equally distributed within foods [33]. Although existing as endogenous components of fresh foods such as fruits and vegetables, BAs can accumulate as the result of uncontrolled microbial enzymatic activity [34]. Foods likely to contain high levels of BA included fish and fish products, dairy products, meat and meat products, fermented vegetables, soy products and alcoholic beverages such as wine and beer (Table 2). The most common BAs in foods are histamine, tyramine, putrescine and cadaverine (Table 2).

The synthesis and accumulation of BA in food requires the presence of the substrate amino acids, bacteria with the appropriate aminoacyl decarboxylase activity, and environmental conditions that allow both for the necessary enzyme action and bacterial growth. Combinations of these factors influence the varieties and quantities of BAs present in foodstuffs (Table 2). Fish and certain varieties of cheese contain the highest amounts of histamine (up to 1000-2000 mg kg-1; Table 1) and are the foods most frequently associated with cases of histamine poisoning [35]. Meat, and particularly cheeses, have the highest concentrations of tyramine. In long-ripened cheeses made from raw milk, tyramine levels can reach over $1000 \mathrm{mg} \mathrm{kg}^{-1}$ [32] (Table 2). 
Table 3. Producer microorganism found in foodstuffs.

\begin{tabular}{|c|c|c|}
\hline Food & Biogenic amine & Producer microorganism \\
\hline Fish & Histamine & $\begin{array}{l}\text { Morganella morganii, Klebsiella pneumonia , Hafnia alvei, Proteus } \\
\text { vulgaris, Proteus mirabilis, Enterobacter cloacae, Enterobacter } \\
\text { aerogenes, Serratia fonticola, Serratia liquefaciens, Citobacter freundii, } \\
\text { Clostridium sp, Pseudomonas fluorescens, Pseudomonas putida, } \\
\text { Aeromonas spp., Pleisomonas shigelloides, Photobacterium spp }\end{array}$ \\
\hline \multirow[t]{3}{*}{ Cheese } & Histamine & Lactobacillus buchneri \\
\hline & Tryamine & $\begin{array}{l}\text { Enterococcus faecalis, Enterococcus faecium, Enterococcus durans, } \\
\text { Entererocccus hirae, Lactobacillus brevis, Lactobacillus curvatus }\end{array}$ \\
\hline & Putrescine & $\begin{array}{l}\text { Enterobacteriaceae (Enterobacter, Serratia, Escherichia, Salmonella, } \\
\text { Hafnia, Citrobacter, Klebsiella) Lactobacillus brevis }\end{array}$ \\
\hline \multirow[t]{5}{*}{ Wine } & Cadaverine & Enterobacteriaceae \\
\hline & Histamine & Oenococcus oeni, Lactobacillus hilgardii, Pediococcus parvulus \\
\hline & Tryamine & $\begin{array}{l}\text { Lactobacillus brevis, Lactobacillus hilgardii, Leuconostoc mesenteroides, } \\
\text { Lactobacillus plantarum, Enterococcus faecium }\end{array}$ \\
\hline & Putrescine & $\begin{array}{l}\text { Lactobacillus brevis, Lactobacillus hilgardii, Leuconostoc mesenteroides, } \\
\text { Lactobacillus plantarum, O. Oeni, Lb. buchneri, Lactobacillus zeae }\end{array}$ \\
\hline & Cadaverine & Enterobacteriaceae \\
\hline \multirow[t]{4}{*}{ Meat } & Histamine & Enterobacteriaceae, Stphylococcus capitis \\
\hline & Tryamine & $\begin{array}{l}\text { Staphylococccus carnosus, Staphylococccus xylosus, Staphylococccus } \\
\text { epidermidis, Staphylococccus saprophyticus, Lactobacillus brevis, } \\
\text { Lactobacillus curvatus, Lactobacillus sakei, Lactobacillus bavaricus, } \\
\text { Carnobacterium divergens, Carnobacterium pisicola }\end{array}$ \\
\hline & Putrescine & $\begin{array}{l}\text { Enterobacteriaceae, M. morganii, S. liquefaciens, Pseudomonas, Lb. } \\
\text { curvatus, Enterococcus }\end{array}$ \\
\hline & Cadaverine & Enterobacteriaceae \\
\hline
\end{tabular}

\section{Biogenic amine-producing microorganisms}

An essential factor in the formation of BAs in foods is the presence of bacterial strains with the capacity to decarboxylate amino acids. This ability has been described in different genera, species and strains of bacteria, both Gram positive and Gram negative. The synthesis of BAs in bacteria may be associated with the supply of energy and to help protect from acid stress $[36,37]$. Additional roles in DNA regulation and as free 
radical scavengers have been suggested [38]. Fish and fish products are among the foods with the highest BA concentrations (mainly histamine), the product of a number of enteric bacteria as well as Pseudomonas (Table 3). Since BA producers are mostly contaminating Gram negative bacteria, many authors have suggested that BAs could be used as an indicator of poor quality or the following of poor manufacturing practices. In fermented products, however, lactic acid bacteria (LAB) are the main BA producers. These can be found in the raw materials, be part of the starter culture, or contaminate the product during its manufacture. A number of authors have suggested the ability to produce BAs to be a negative trait when selecting a starter, secondary or adjunct culture to be used in making fermented products [39, 40].

Although Oenococcus oeni was initially considered the main bacterial species responsible for histamine accumulation in wine, recent studies have shown that strains of Lactobacillus hilgardii and Pediococcus parvulus may in fact be the culprits [41, 42]. Tyramine is the most abundant and commonly detected BA in cheese and fermented meat products, in which LAB strains of Enterococcus and Lactobacillus are the main producers. Putrescine synthesis was initially associated with Gram negative bacteria, particularly members of the Enterobacteriacea [43, 44]. However, recent reports cite the ability of certain LAB strains of Lb. brevis isolated from wine [45] and Lb. curvatus and E. faecalis isolated from cheese (unpublished results) to produce putrescine by agmatine deamination instead of the ornithine decarboxylation pathway; their contribution to putrescine production in food cannot, therefore, be ruled out. In fact, $\mathrm{LAB}$ are the main bacteria responsible for putrescine production in wine $[46,42]$.

Current knowledge regarding BA-producing microorganisms varies according to the species or strain in question. In some cases, the genes encoding BA-producing enzymes (decarboxylation and transporter) have been sequenced and regulatory studies have been performed (for a review see 47). In others, data have been obtained after the isolation of the producer microorganism using decarboxylating media [48].

\section{Toxicological effects}

Owing to their importance in cellular physiology, the concentrations of BAs present in cells and tissues are tightly regulated at the levels of biosynthesis, catabolism, uptake 
and efflux [12]. The ingestion of foods rich in BAs could, unfortunately, alter the equilibrium achieved. Studies with adult rats have shown that, following ingestion, BAs rapidly appear in the gut, blood and a number of organs [49]. Moreover, several studies have highlighted toxicological effects for some BAs - even in small amounts - following their oral administration $[14,50,51]$. The intake of these toxic compounds can induce several digestive, circulatory and respiratory symptoms (Table 1).

Figure 1: Fate of biogenic amines in the human intestinal tract.

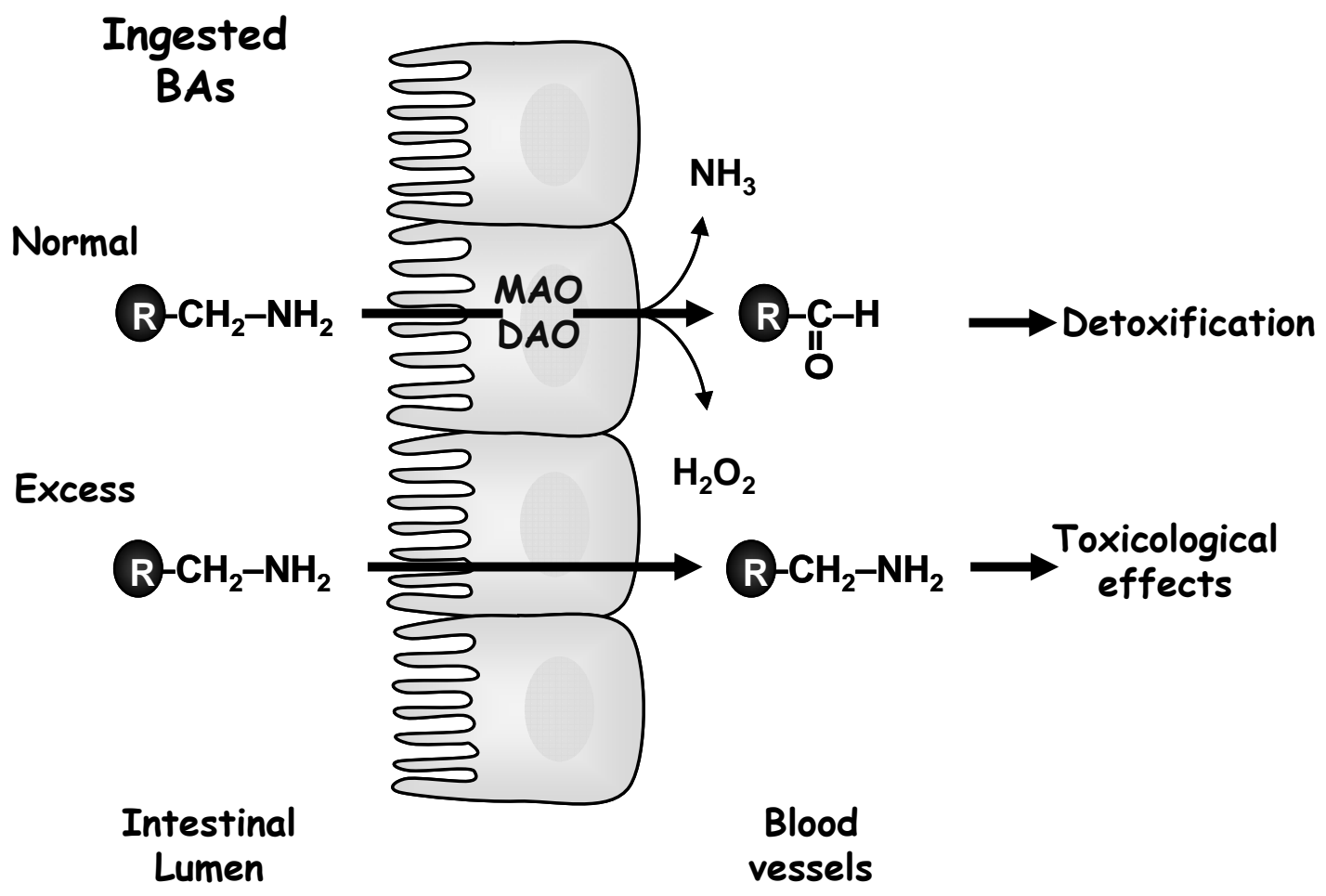

Oxidation is the main route of BA detoxification following ingestion "Fig. (1)", although methylation and acetylation have been also implicated in the detoxification of histamine $[52,53]$. Detoxifying oxidation is carried out by specific amine oxidases (AOs). These enzymes are usually classified as mono- (MAO) or diamine oxidases (DAO) depending on the number of amino groups preferentially oxidised. MAO enzymes have been classified according to their inhibitors as MAO-A and MAO-B 
enzymes. MAO-As deaminate serotonin in the central nervous system and also deal with dietary monoamines in the gastrointestinal system. MAO-Bs are found predominantly in the liver and muscle and deaminate dopamine and phenylethylamine. Histamine and putrescine are deaminated by a DAO in the gut, providing protection against the normal concentrations present in foods [54].

The severity of the clinical symptoms caused by BAs depends on the amount and variety ingested, individual susceptibility, and the level of detoxification activity in the gut. This activity can differ for genetic reasons and under the influence of inhibitory compounds (MAOIs and DAOIs). Certain antidepressants and isoflavones (and their metabolites) have been described to act as MAOIs. Even when taken in association with a trace amine-rich diet, hypertensive crises have been reported, especially in elderly women $[54,55,56]$. Putrescine, tyramine and $\beta$-phenylethylamine concentrations are also affected by MAOIs and DAOIs $[57,58]$. The role of these inhibitors has been shown in experiments in rats and guinea pigs, in which cadaverine, putrescine and tyramine potentiate histamine toxicity $[53,59]$. Smoking seems to be another risk factor that enhances the probability to suffering BA-associated symptoms; cigarette smokers can show a 30\% reduction in their MAOA and MAOB activities [60].

Alcohol and acetaldehyde have been described to enhance the toxic effects of BAs by increasing the permeability of the intestinal wall to these compounds. This effect is of particular importance when alcoholically-fermented beverages are contaminated with high concentrations of BAs, or when BA-containing foods are consumed with an accompanying alcoholic drink [33, 51].

The intake of foods with high BA loads, or the inadequate detoxification of BAs, can lead to their entering the systemic circulation, inducing the release of adrenaline and noradrenaline and provoking gastric acid secretion, an increased cardiac output, migraine, tachycardia, increased blood sugar levels and higher blood pressure [18]. The most serious and studied toxic effects of BA-rich foods have been investigated in patients treated with MAOIs [58, 62, 63]. Indeed, the toxic effects of some BAs were first discovered in patients treated with MAOIs who suffered headaches after eating cheese $[55,64]$. Depending on the severity of the symptoms, the effects of BAs are described as a reaction, intolerance, or intoxication or poisoning. Reaction symptoms include nausea, sweating, rashes, slight variations in blood pressure and mild headache. 
If the amount ingested is too great for efficient detoxification to be performed, or if the detoxification system is strongly inhibited, the symptoms become more severe (those of intolerance) with vomiting, diarrhoea, facial flushing, a bright red rash, bronchospasms, tachycardia, oral burning, hypo- or hypertension and migraine. In exceptional cases BA poisoning may occur, involving a hypertensive crisis (blood pressure $>180 / 120 \mathrm{mmHg}$ ) that can lead to end-organ damage in the heart or the central nervous system [55].

\section{Histamine}

Although the onset of histamine intake symptoms after eating fish (especially members of the scombroid family) were first recorded in sailors some centuries ago, the first articles that demonstrated the relationship between the histamine present and intoxication were published in France in 1946 [65, 66], and it was not until some decades later that a report linking histamine intoxication and the consumption of other foods (including cheese) was published [35].

The consumption of foods with high concentrations of histamine can cause the same symptoms as those seen in an allergic reaction, leading to an incorrect diagnosis (Table 1). However, an intoxication can be distinguish from an allergy if there is no previous history of any such allergy, when there is an outbreak of problems involving different patients over a short period of time, and when the food eaten is suspected of being histamine-rich [35].

No toxicological effect is reported when food histamine levels range from 6 to 25 $\mathrm{mg} / \mathrm{meal}$. The ingestion of $75 \mathrm{mg}$ of histamine, however, is reported to cause intoxication symptoms in healthy people [51, 67]. The ingestion of foods with a histamine concentration of $400 \mathrm{mg} \mathrm{kg}^{-1}$ is considered dangerous to health [35], and certainly the intake of approximately $1000 \mathrm{mg}$ of histamine is associated with severe intoxications [67]. An incubation period ranging from a few minutes to a few hours may be necessary, with symptoms usually noticeable for only a few hours [53].

Ingested histamine first reaches the gastrointestinal tract (GIT) where, if the detoxification system is not able to eliminate it, it binds to specific receptors. The first effect of this is the contraction of the intestine's smooth muscle and the dilation of the surrounding blood vessels [3]. This is followed by symptoms similar to those of an 
allergic response (Table 1). Besides headache, gastrointestinal symptoms including diffuse stomach ache, colic, flatulence, and diarrhoea can occur, as well as tachycardia, extrasystoles, hypotension, nasal secretion, bronchospasm, oedema (eyelids) and urticaria [3]. High histamine concentrations and a diminished DAO activity have been related to a number of inflammatory and neoplastic diseases such as Crohn's disease, ulcerative colitis and colorectal neoplasms [4].

\section{Tyramine}

The first signs of trace amines (tyramine and $\beta$-phenylethylamine) being associated with hypertension were discovered by a neurologist who noticed that his wife, who was receiving MAOI treatment, had severe headaches (caused by cerebral vasoconstriction followed by dilation) when eating cheese [55]. The first observation that tyramine might be responsible for headaches and migraines was made in 1967 [64]. This was further supported by studies that correlated the ingestion of tyramine-rich foodstuffs with migraine crises [68].

In healthy men, an average $500 \mathrm{mg}$ of orally administrated tyramine is required to increase the systolic blood pressure (under laboratory conditions) by at least $30 \mathrm{mmHg}$ over that achieved by a placebo. Since women appear to be more sensitive to tyramine, the amount required to achieve the same effect in them might be lower [50]. In contrast, other authors report a concentration of over $125 \mathrm{mg} \mathrm{kg}^{-1}$ to be required for any effect to be seen in normal individuals, and indicate a concentration of $6 \mathrm{mg} \mathrm{kg}^{-1}$ to be potentially toxic when ingested in combination with MAOIs [69].

An excess of tyramine in the GIT (i.e., which cannot be quickly detoxified by MAOs), can lead to its entering the systemic circulation, in which it can reach adrenergic nerve terminals, be $\beta$-hydroxylated to octopamine, and stored in the vesicles with the gradual displacement of norepinephrine. This leads to a transient increase in blood pressure. Nerve stimulation results in the release of relatively small amounts of norepinephrine and certain amounts of octopamine, causing the functional impairment of sympathetic nerve transmission. This results in headaches, migraines, nausea and vomiting [70]. 
In some individuals the increase in blood pressure results in a hypertensive crisis, a rare but critical elevation of the blood pressure $(>180 / 120 \mathrm{mmHg})$. This can cause end-organ damage to the heart or central nervous system [55].

Apart from the systemic toxicological effects of tyramine (Table 1), this BA can also have an effect on the intestinal microbiota. Certainly, tyramine is known to enhance the adherence of the enteropathogen E. coli $1057 \mathrm{H}$ to epithelial cells [71].

Raised levels of tyramine in the brain have been associated with neurological disorders such as schizophrenia, Parkinson's disease, depression and Reyes' syndrome [9, 72]. Although tyramine is not able to cross the blood-brain barrier [73], its effect appears to be transmitted via the afferent pathway in the central vagal pre-ganglionic neurons that regulate the pacemaker activity of the heart [74].

\section{Putrescine and polyamines}

The daily polyamine intake for an adult is estimated to vary between 350 and $550 \mu \mathrm{mol}$ [75]. Thirty minutes after the intragastric administration of $\left[{ }^{14} \mathrm{C}\right]$ putrescine, radioactivity was detected in all segments of the gut, in the blood, and in various organs of adult rats [49], highlighting the potential need to control the intake of putrescine [76]. In addition, bacteria in the lumen of the large intestine synthesise polyamines, perhaps accounting for some $13 \%$ of the total [77]. These luminal polyamines of dietary and bacterial origin play a key role in the regulation of total polyamine homeostasis.

Although non-direct toxic effects have been described for putrescine and other polyamines, their role in the regulation of cell growth, proliferation and the maturation of the GIT $[14,78]$ means the amounts present in the latter need be tightly regulated; a disturbed equilibrium could lead to the dysregulation of certain physiological functions (Table 1). Polyamines and their metabolising enzymes are tightly linked to the proliferation of neoplasms in the GIT, and there is increasing evidence that putrescine and spermidine have a role in promoting the malignant transformation of cells $[78,79]$. Among the several biochemical alterations seen in such cells, one of the most consistent is the change in the intracellular polyamine content. Colorectal cancer cells have a higher polyamine content than the adjacent mucosa or equivalent normal tissue [80], highlighting the possible importance of exogenous putrescine in their development [79]. 
Further, the transport of putrescine from the intestine to the blood is enhanced by high concentrations of the same [81]. In fact, it is recommended that the dietary intake of putrescine be reduced in patients with familial adenomatous polyposis; in a murine model dietary putrescine increased the malignancy grade of adenomas [82]. Elevated concentrations of putrescine have also been detected in gastric carcinomas caused by Helicobacter pylori. Putrescine levels are restored if the microbial infection is eliminated [83].

Putrescine can also interact with certain pathogenic microorganisms since it is an essential component in their outer structure, and has been reported related to virulence factors in many Gram positive and Gram negative pathogens [83]. Exogenous putrescine can activate the swarming phenotype needed for pathogenesis in some Proteus mirabilis mutants [84].

Apart from a direct effect in promoting the transformation of cells, histamine and polyamines subjected to heat can give rise to secondary amines that can combine with nitrites, their salts generating nitrosamines of known carcinogenic, mutagenic and teratogenic activity $[85,86]$. This is of particular importance in some fermented meat products to which nitrates and nitrites are added as preservatives [61].

\section{Recommended limits of biogenic amines in food}

It is very difficult to establish a uniform maximum limit for ingested BAs since their toxic effects depend on the type of amine in question, the presence of modulating compounds, and by the efficiency of an individual's detoxification mechanism. Several studies have also suggested that the absorption, metabolism and/or potency of one BA might be modified by the presence of another, which might explain why aged cheese is more toxic than its equivalent amount of histamine in aqueous solution [52].

Laboratory studies on the effects of BA face a number of methodological problems. Most studies have focused on the effect of individual BAs administered intravenously to laboratory animals or healthy volunteers, but these results are difficult to transfer to food intake since the intravenous response is several times higher than that obtained with oral administrations [87]. Neither are the results of physiological response studies in animals always transferable to humans. In the particular case of trace amines 
(tyramine and phenylethylamine) the type, number and distribution of the TAARs vary greatly among species [9]. The effects of trace amines are mainly based on clinical observations; no meta-analyses that might confirm their effects are therefore possible [88]. Ingestion limits based on case reports may be too high since, usually, only cases of BA poisoning are reported $[35,67]$.

Although more in-depth studies on the toxic effects of BAs are necessary, some studies have reported minimum toxic levels for some BAs. Wöhrl et al. [51] reported that 75 $\mathrm{mg}$ of pure liquid oral histamine - a dose common in normal meals - can provoke immediate as well as delayed symptoms in $50 \%$ of healthy females with no history of food intolerance. A concentration of over $125 \mathrm{mg} \mathrm{kg}^{-1}$ of tyramine is considered to be toxic in normal individuals - almost 100 times the concentration considered potentially toxic when ingested in combination with MAOIs [69]. Threshold values of $100 \mathrm{mg} \mathrm{kg}^{-1}$ for tyramine and $30 \mathrm{mg} \mathrm{kg}^{-1}$ for phenylethylamine have been suggested [89]. However, since there is always more than one type of BA in food, a maximum total BAs level of $750-900 \mathrm{mg} \mathrm{kg}^{-1}$ has been proposed [89, 90 respectively].

Currently, the only BA for which maximum limits have been set in the EU and the USA is histamine. European legislation (Commission Regulation (EC) 2073/2005) limits histamine levels to $200 \mathrm{mg} \mathrm{kg}^{-1}$ in fresh fish and up to $400 \mathrm{mg} \mathrm{kg}^{-1}$ for cured fishery products. The US Food and Drug Administration considers a histamine level of $\geq 500$ $\mathrm{mg} \mathrm{kg}^{-1}$ to be a danger to health. This agrees with values cited in histamine intoxication reports in which over 500-1000 $\mathrm{mg} \mathrm{kg}^{-1}$ of food had been ingested [67, 91]. A maximum level of $2 \mathrm{mg}^{-1}$ of histamine has been established for alcoholic beverages in some countries, but only for imported products, suggesting the use of BA limits to protect commercial interests.

No clear data on acceptable histamine or other BA concentrations are available for other foods, although concentrations of $>1000 \mathrm{mg} \mathrm{kg}^{-1}$ are inadvisable (Table 2) [32, 67]. Such levels would render foods "unsafe" in terms of the legislation for histamine. Despite the legal vacuum with respect to other BAs, a general consensus exists regarding the need to reduce their concentration in food. Over recent years, a number of methods for the accurate determination of BA concentrations in foodstuffs have been developed (for a review see 92), including novel, rapid detection systems [93]. Designed for testing final food products, these systems could help in food quality 
control. However, to prevent the synthesis and accumulation of BAs during the manufacturing processes, the technological factors that affect their content in foods should be taken into account $[18,46,61,94]$. It is clear that the essential factor in the appearance of BA is the presence of microorganisms with decarboxylating activity. The development of new methods for detecting and quantifying BA producers in raw materials and over the manufacturing processes should enhance the quality and safety of food products that reach consumers [95]. The most promising in preventing BA accumulation are the real time quantitative PCR (RT-qPCR) methods developed for the early detection and quantification of BA producers in a number of food products [96, 97, 98, 99,100]. Such tools can show when preventive measures need to be taken during manufacture, manipulation and storage.

\section{Conclusions}

BAs play essential roles in the normal development, metabolism and physiological functions of humans. However, when ingested in high concentrations they can cause a range of toxicological effects. The presence of some of these toxic compounds has been directly or indirectly related to a number of carcinogenic effects.

The main source of ingested BAs are foodstuffs in which the metabolic activity - mainly amino acid decarboxylation - of certain microorganism causes their accumulation at concentrations that can pose a health risk. Most studies into the presence of BAs in foods have been based on the content detected in individual food types; only a few have looked into the real amounts of BAs that are ingested (or could be ingested) in the normal diet. Such studies would help provide a picture of the real dangers of BA ingestion; combined with a record of symptoms, this information could be used to establish safe BA levels. However, more double-blind, placebo-controlled clinical studies based on realistically ingested amounts will be needed for such levels to de ascertained. It should also be remembered that BAs may show synergistic effects; the presence of potential detoxification inhibitors and the administration pathway should also be taken into account.

While more work is needed on the harmful effects of BAs, sufficient data are available for reasonable limits to be imposed in order to ensure the health of consumers. It would 
be reasonable to adopt preventive "m"/ "M" limits of 200 and $500 \mathrm{mg}$ of individual BAs per $\mathrm{kg}$ for foods not yet covered by legislation but which often have high concentrations (such as cheese). Such limits could be easily kept to by current food manufacturing practices and would serve as a base to be confirmed by clinical studies. Progress in understanding the factors involved in the accumulation of BAs and the development of new analytical and microbiological technologies should allow the food industry to keep BA concentrations below dangerous limits with no great effort. It may then even be possible to certify carefully manufactured products as BA-free; this would be of great interest to more sensitive individuals.

\section{Acknowledgments}

V. Ladero is the beneficiary of an I3P - CSIC contract financed by the European Social Fund. M. Calles is the recipient of a $\mathrm{PhD}$ fellowship (FPI programme) from the Spanish Ministry of Education and Science. The authors thank Adrian Burton for linguistic assistance. This work was supported by the Ministry of Education and Science, Spain (AGL2006-01024) and the European Community's Seventh Framework Programme (KBBE-CT-2007-211441).

\section{References}

[1] Tabor CW, Tabor H. Polyamines in microorganisms. Microbiol Rev 1985; 49: 8199.

[2] Igarashi, K, Ito K, and Kashiwagi, K. Polyamine uptake systems in Escherichia coli. Res. Microbiol 2001; 52: 271-8.

[3] Jarisch R. Histamin-Intoleranz. Histamin und Seekrankheit ( $2^{\text {nd }}$ ed.), Georg Thieme Verlag, Stuttgart, New York 2004. 
[4] Maintz L, Novak N. Histamine and histamine intolerance. Am J Clin Nutr 2007; 85: 1185-96.

[5] Jørgensen EA, Knigge U, Warberg J, Kjær A. Histamine and the regulation of body weight. Neuroendocrinology 2007; 86: 210-4.

[6] Ranganchari PK. Histamine: mercurial messenger in the gut. Am J Physiol 1992; 262: 1-13.

[7] Coruzzi G, Morini G, Adami M, Grandi D. Role of histamine H3 receptors in the regulation of gastric functions.. J Physiol Pharmacol 2001; 52: 539-53.

[8] Passani MB, Giannoni P, Bucherelli C, Baldi E, Blandina P. Histamine in the brain: beyond sleep and memory Biochem Pharmacol. 2007; 73: 1113-22.

[9] Berry MD. The potential of Trace amines and their receptors for treating Neurological and Psychiatric Diseases. Rev Recent Clin Trials 2007; 2: 3-19.

[10] Lindemann L, Ebeling M, Kratochwil NA, Bunzow JR, Grandy DK, Hoener MC. Trace amine-associated receptors form structurally and functionally distinct subfamilies of novel G protein-coupled receptors. Genomics 2005; 85: 372-85.

[11] Maguire JJ, Barriocanal FP, Davenport AP. Are vasoconstrictor responses to tyramine in human blood vessels, in vitro, mediated by the orphan trace amine receptor TA1. Br. J. Pharmacol 2002; 131: 71P

[12] Linsalata M, Russo F. Nutritional factors and polyamine metabolism in colorectal cancer. Nutrition 2008; 24: 382-9

[13] Deloyer P, Peulen O, Dandrifosse G. Dietary polyamines and non-neoplastic growth and disease. Eur J Gastroenterol Hepatol 2001; 13: 1027-32.

[14] Dufour C, Dandrifosse G, Forget PP, Vermesse F, Romain N, Lepoint P. Spermine and spermidine induce intestinal maturation in the rat. Gastroenterology 1988; 95: 1126.

[15] Dandrifosse G, Peulen O, El Khefif N, Deloyer P, Dandrifosse AC, Grandfils C. Are milk polyamines preventive agents against food allergy? Proc Nutr Soc 2000; 59: 81-6.

[16] Moret S, Smela D, Populin T, Conte LS. A survey on free biogenic amine content of fresh and preserved vegetables. Food Chem 2005; 89: 355-61.

[17] Kalac P, Savel J, Krizek M, Petikanova T, Prokopova M. Biogenic amine formation in bottled beer. Food Chem 2002; 79: 431-4. 
[18] Shalaby AR. Significance of biogenic amines in food safety and human health. Food Res Int 1996; 29: 675-90.

[19] Su SC, Chou SS, Chang PC, Hwang DF. Determination of biogenic amines in fish implicated in food poisoning by micellar electrokinetic capillary chromatography. J. Chromatogr 2000; 749: 163-9.

[20] Zhang H, Guo Z, Zhang F, Xu Q, Liang X. HILIC for separation of co-eluted flavonoids under RP-HPLC mode. J Sep Sci 2008; 31: 1623-7.

[21] Sanceda NG, Suzuki E, Ohashi M, Kurata T. Histamine behavior during the fermentation process in the manufacture of fish sauce. J Agric Food Chem 1999; 47: 3596-600.

[22] Marcobal A, de las Rivas B, Moreno-Arribas MV, Muñoz R. Evidence for horizontal gene transfer as origin of putrescine production in Oenococcus oeni RM83. Appl Environ Microbiol 2006; 72: 7954-8.

[23] Bodmer S, Imark C, Kneubühl M. Biogenic amines in foods: Histamine and food processing. Inflamm Res 1999; 48: 296-300.

[23] Bover-Cid S, Izquierdo-Pulido M, Marie-Fount A, Vidal-Carou MC. Biogenic mono, di-and polyamine contens in Spanish wines and influence of limited irrigation. Food Chem 2006; 96: 43-7.

[24] Garai G, Ibarbury I, Berregi I, Claisse O, Lonvaud-Funel A, Irastorza A, Dueñas MT. Glycerol metabolism an bitterness producing lactic acid bacteria in cidermaking. Int J Food Microbiol 2007; 121: 253-61.

[25] Favaro G, Pastore P, Saccani G, Cavalli S. Determination of biogenic amines in fresh and processed meta by ion chromatography and integrated pulsed amperometric detection on Au-electrode. Food Chem 2007; 105: 1652-8.

[26] Hernández-Jover T, Izquierdo-Pulido M, Veciana-Nogues MT, Marine-Font A, Vidal-Carou MC. Effect of starter cultures on biogenic amine formation during fermented sausage production. J Food Prot 1997; 60: 825-30.

[27] Vidal-Carou MC, Veciana-Nogués MT, Mariné-Font A. Spectrofluometric determination of histamine in fish and meta procducts. J Assoc Off Anal Chem 1990; 73: $565-7$. 
[28] Novella-Rodríguez SN, Veciana-Nogues MT, Roig-Sagues AX, Trujillo-Mesa AJ, Vidal- Carou MC. Evaluation of biogenic amines and microbial counts throughout the ripening of goat cheeses from pasteurized and raw milk. J Dairy Res 2004; 71: 245-52. [29] Bodmer S, Imark C, Kneubühl M. Biogenic amines in foods: Histamine and food processing. Inflamm Res 1999; 48: 296-300

[30] Valsamaki K, Michaelidou A, Polychroniadou A. Biogenic amine production in Feta cheese. Food Chem 200; 71: 259-66.

[31] Pinho P, Pintado AIE, Gomes AMP, Pintado MME, Malcasa FX, Ferreira IM. Interrelationships among microbial, physiochemical, and biochemical properties of Terrincho cheese, with emphasis on biogenic amines. JFood Prot 2004; 67: 2779-85.

[32] Fernández M, Linares DM, Del Río B, Ladero V, Álvarez MA. HPLC quantification of biogenic amines in cheeses: correlation with PCR-detection of tyramine-producing microorganism. J Dairy Res 2007; 74: 276-282.

[33] Silla-Santos MH. Biogenic amines: their importance in foods. International J Food Microbiol 1996; 29: 213-31.

[34] Halàsz A, Baráth A, Simon-Sarkadi L, Holzapfel WH. Biogenic amines and their production by microorganisms in food. Trends Food Sci. Technol 1994; 5: 42-9.

[35] Taylor SL. Histamine poisoning associated with fish, cheese and other foods. Report VPH/FOS/85.1. WHO press 1985;1-48.

[36] Konings WN, Lolkema JS, Bolhuis H, vanVeen HW, Poolman B, Driessen AJM. The role of transport processes in survival of lactic acid bacteria. Energy transduction and multidrug resistance. Antonie Van Leeuwenhoek 1997; 71: 117-28.

[37] Foster, JW. Escherichia coli acid resistance: tales of an amateur acidophile. Nat. Rev. Microbiol 2004; 2: 898-907.

[38] Wortham BW, Patell CN, Oliveira MA. Polyamines in bacteria: pleiotropic effects yet specific mechanisms. Adv Exp Med Biol 2007; 603: 106-15.

[39] Crow V, Curry B, Hayes M. The ecology of non-starter lactic acid bacteria (NSLAB) and their uses as adjuncts in New Zeland Cheddar. Int Dairy J 2001; 11: 27583.

[40] Lonvaud-Funel A. Biogenic amines in wines: role of lactic acid bacteria. FEMS Microbiol Lett 2001; 199: 9-13. 
[41] Lucas P, Wolken WAM, Claisse O, Lolkema JS, Lonvaud-funel A. Histamine producing pathway encoded on an unstable plasmid in Lactobacillus hilgardii 0006. Appl Environ Microbiol 2005; 71: 1417-24.

[42] Moreno-Arribas MV, Polo MC. Occurrence of lactic acid bacteria and biogenic amines in biologically aged wines. Food Microbiol 2008; 25: 875-81

[43] Marino M., Maifreni M, Moret S, Rondinini G. The capacity of Enterobacteriaceae species to produce biogenic amines in cheese. Lett. Appl. Microbiol 2000; 31: 169-73.

[44] Chaves-López C, De Angelis M, Martuscelli M, Serio A, Paparella A, Suzzi G. Characterization of the Enterobacteriaceae isolated from an artisanal Italian ewe's cheese (Pecorino Abruzzese). J Appl Microbiol 2006; 101: 353-60

[45] Lucas PM, Blancato VS, Claisse O, Magni C, Lolkema JS, Lonvaud-Funel A. Agmatine deiminase pathway genes in Lactobacillus brevis are linked to the tyrosine decarboxylation operon in a putative acid resistance locus. Microbiology 2007; 153: 2221-30.

[46] Ancín-Azpilicueta C, González-Marco A, Jiménez-Moreno N. Current knowledge about the presence of amines in wine. Crit Rev Food Sci Nutr 2008; 48: 257-275.

[47] Linares DM, Martín MC, Ladero V, Alvarez MA, Fernández M. Biogenic amines in dairy products Crit Rev Food Sci Nutr 2009; In press

[48] Bover-Cid S, Halzapfel WH. Improved screening procedure for biogenic amine production by Lactic acid bacteria. Int J Food Microbiol 1999; 53: 33-41.

[49] Bardocz S, Duguid TJ, Brown DS, Grant G, Pusztai A, White A, Ralph A. The importance of dietary polyamines in cell regeneration and growth. Br J Nutr 1995; 73: 819-29.

[50] van den Berg CM, Blob LF, Kemper EM, Azzaru AJ. Tyramine pharmacokinetics and reduced bioavailability with food. J Clin Pharmacol 2003; 43: 604-9.

[51] Wöhrl S, Hemmer W, Focke M, Rappersberger K, Jarisch R. Histamine intolerance-like symptoms in healthy volunteers after oral provocation with liquid histamine. Allergy Asthma Proc 2004; 25: 305-11.

[52] Taylor SL. Histamine food poisoning: Toxicology and clinical aspects. CRC Crit Rev Toxicol 1986; 17: 91-128.

[53] Lehane L, Olley J. Histamine fish poisoning revisited. Int J Food Microbiol 2000; 58: $1-37$ 
[54] McCabe-Sellers BJ, Staggs CG, Bogle ML. Tyramine in foods and monoamine oxidase inhibitor drugs: A crossroad where medicine, nutrition, pharmacy, and food industry converge. J Food Compost Anal 2006; 19: 58-65.

[55] Blackwell B. Hypertensive crisis due to monoamine-oxidase inhibitors. Lancet $1963 ; 2: 849-50$.

[56] Hutchins AM, McIver IE, Johnston CS. Hypertensive crisis associated with high dose soya isoflavone supplementation in a post-menopausal woman: a case report. BMC Women's Health 2005; 5: 1-5.

[57] Sattler J, Häfner D, Klotter HJ, Lorenz W, Wagner PK. Food-induced histaminosis as an epidemiological problem: plasma histamine elevation and haemodynamic alterations after oral histamine administration and blockade od diamine oxidase (DAO). Ahents Action 1988; 23: 361-5.

[58] Stratton JE, Hutkins RW, Taylor SL. Biogenic amines in cheese and other fermented foods. A review. J. Food Prot 1991; 54: 460-70.

[59] Bjeldanes LF, Schutz DE, Morris MM. On the aetiology of scombroid poisoning: cadaverine potentiation of histamine toxicity in the guinea pig. Food Cosmetic Toxicol 1978; 16: 157-9.

[60] Berlin I, Anthenelli RM. Monoamine oxidases and tobacco smoking. Int J Neuropsychopharmacol 2001; 4: 33-42.

[61] Ruiz-Capillas C, Jimenez-Colmenero F. Biogenic amines in meat and meat products. Crit Rev Food Sci Nutr 2004; 44: 489-99.

[62] Gardner DM, Shulman KI, Walker SE, and Tailor SA. The making of a user friendly MAOI diet. J Clin Psychiatry 1996; 57: 99-104

[63] Rapaport MH. Dietary restrictions and drug interactions with monoamine oxidase inhibitors: the state of the art. J Clin Psychiatry 2007; 8: 42-6.

[64] Hanington E. Preliminary reports on tyramine in Headache. Brit med J 1967; 2: $550-1$.

[65] Legroux R, Levaditi JC, Segond L. Methode de mise en evidence de l'histamine dans les aliments causes d'intoxications collectives a l'aide de l'inoculation au cobaye. Comp. Rend. Soc. Biol 1946; 140: 863-4.

[66] Legroux R, Levaditi JC, Bouidin G, Bovet D. Intoxications histaminiques collectives consecutives a l'ingestion de thon frais. Presse Med 1964; 54: 545-6. 
[67] Rauscher-Gabernig E, Grossgut R, Bauer F, Paulsen P. Assessment of alimentary histamine exposure of consumers in Austria and development of tolerable levels in typical foods. Food Control 2009; 20: 423-29.

[68] Coutts RT, Baker GB, Pasutto FM. Foodstuffs as sources of psychoactive amines and their precursors: content significance and identification. Adv Drug res 1986; 15: $169-232$.

[69] McCabe-Sellers BJ. Dietary tyramine and other pressor amines in MAOI regimens: a review. J Am Diet Assoc 1986; 86: 1059-64

[70] Weiner N. In The Pharmacological Basis of Therapeutics, 6th ed.; Goodman, A. G., Goodman, L. S., Gilman, A., Eds.; Macmillan Publishing Co., Inc.: New York, $1980 ; 158-9$.

[71] Lyte M. The biogenic amine tyramine modulates the adherence of Escherichia coli O157:H7 to intestinal mucosa. J Food Prot. 2004; 67: 878-83.

[72] Premont RT, Gainetdinov RR, Caron MG. Following the trace of elusive amines. Proc. Natl. Acad. Sci. U. S. A 2001; 98: 9474-5.

[73] McCulloch J, Deshmukh VD, Harper AM. Indirect sympathetic agents and cerebral blood flow and metabolism. Eur. J. Pharmacol 1978; 47: 11-8.

[74] Khwanchuea R, Mulvany MJ, Jansakul C. Cardiovascular effects of tyramine: Adrenergic and cholinergic interactions. Eur J Pharmacol 2008; 579: 308-17.

[75] Bardocz S, Grant G, Brown DS, Ralph A, Pusztai A. Polyamines in food: implications for growth and health. J Nutr Biochem 1993; 4: 66-71.

[76] Seiler N, Raul F. Polyamines and intestinal tract. Crit Rev Clin Lab Sci. 2007; 44: $365-411$

[77] Pusztai A, Naughton P, Grant G, Bardocz S. In: Bardocz S, Koninkx J, Grillo M, White A Ed. Contibution of gut bacteria to systemic polyamine pools in the rat. In: Biogenically active amines in food. Luxembourg, European Commision. 1999; 50-4.

[78] Seiler N, Atanssov CL, Raul F. Polyamine metabolism as target for cancer chemoprevention. Int. J. Oncol 1998; 13: 993-1006.

[79] Gerner EW, Meyskens FL. Polyamines and cancer: old molecules, new understanding. Nat Rev Cancer 2004; 4: 781-92.

80] Wallace HM, Caslake R. Polyamines and colon cancer. Eur J Gastroenterol Hepatol 2001; 13: 1033-9. 
[81] Desury G, Moulinoux JP, Delcros JG. Alteration of intestinal putrescine uptake in tumour-bearing rats. Int J Oncol 2002; 21: 569-76.

[82] Ignatenko NA, Besselsen DG, Roy UK, Stringer DE, Blohm-Mangone KA, Padilla-Torres JL, Guillen-R JM, Gerner EW. Dietary putrescine reduces the intestinal anticarcinogenic activity of sundilac in a murine model of familial adenomatosus poluposis. Nutr Cancer 2006; 56: 172-81.

[83] Shah P, Swiatlo E. A multifaceted role for polyamines in bacterial pathogens. Mol Microbiol 2008; 68: 4-16.

[84] Sturgill G, Rather PN. Evidence that putrescine acts as an extracellular signal required for swarming in Proteus mirabilis. Mol Microbiol 2004; 51: 437-46.

[85] Wathersen JJ, Scanlan RA, Bills DD, Libbey LM. Formation of heterocyclic Nnitrosamines from the reaction of nitrite and selected primary diamines and amino acids. J Agric Food Chem 1975; 23: 898-902.

[86] Glória MB, Vale SR. Determination of biogenic amines in cheese. J AOAC Int. 1997; 80: 1006-12

[87] Simpson GM, White KW. Tyramine studies and the safety of MAOI drugs. J Clin Psychiatry 1984; 45: 59-61.

[88] Jansen SC, van Dusseldorp M, Bottema KC, Dubois AEJ. Intolerance to dietary biogenic amines: a review. Ann Allergy Asthma Immunol 2003; 91: 233-41.

[89] ten Brink B, Damink C, Joosten HMLJ, Huis in't Veld JHJ. Occurrence and formation of biologically active amines in foods. Int J Food Microbiol 1990; 11: 73-84. [90] Spanjer MC, van Roode BASW. Towards a regulatory limit for biogenic amines in fish, cheese and sauerkraut. De Ware(n)-Chemicus 1991; 21: 139-167.

[91] Taylor SL. Histamine poisoning associated with fish, cheese and other foods. FAO/WHO monograph CX/PH 1983, 83-111.

[92] Önal A. A review: Current analytical methods for the determination of biogenic amines in foods. Food Chem 2007; 103: 1475-86.

[93] Jayarajah, CN, Skelley AM, Fortner AD, Mathies RA. Analysis of Neuroactive Amines in Fermented Beverages Using a Portable Microchip Capillary Electrophoresis System. Anal. Chem 2007; 79: 8162-9. 
[94] Ladero V, Fernández M, Álvarez MA. Effect of post-ripening processing on the histamine and histamine-producing bacteria contents of different cheeses. Int Dairy J 2009; In press. doi:10.1016/j.idairyj.2009.05.010.

[95] Landete JM, de Las Rivas B, Marcobal A, and Muñoz R. Molecular methods for the detection of biogenic amine-producing bacteria on foods. Int. J. Food Microbiol 2007; 117: 258-69.

[96] Fernández M, del Río B, Linares DM, Martín MC, Álvarez MA. Real-time polymerase chain reaction for quantitative detection of histamine-producing bacteria: use in cheese production. J Dairy Sci 2006; 8: 3763-9.

[97] Torriani S, Gatto V, Sembeni S, Tofalo R, Suzzi G, Belletti N, Gardini F, BoverCid S. Rapid detection and quantification of tyrosine decarboxylase gene $(t d c)$ and its expression in gram-positive bacteria associated with fermented foods using PCR-based methods. J Food Prot 2008; 71: 93-101.

[98] Nannelli F, Claisse O, Gindreau E, de Revel G, Lonvaud-Funel A, Lucas PM. Determination of lactic acid bacteria producing biogenic amines in wine by quantitative PCR methods. Lett Appl Microbiol 2008; 47: 594-9.

[99] Ladero, V, Linares DM, Fernández M, Álvarez MA. Real time quantitative PCR detection of histamine-producing lactic acid bacteria in cheese: Relation with histamine content. Food Res Int 2008; 41: 1015-9.

[100] Ladero V, Martínez N, Martín MC, Fernández M, Alvarez MA. qPCR for quantitative detection of tyramine-producing bacteria in dairy products. Food Res Int 2010; 43: 289-95. 